\title{
Cultural- and Traditional-ecological Perspectives in Saami Religion
}

\author{
By Phebe Fjellström
}

There are often certain details in Saami source materials which may cause the scholar to scratch his head. The information seems to part quite distinct from its context and often contains a number of conflicting components. Information of this kind is to be found in Rheen's account of the Lulea Saamis recorded between the years 1666 and 1671: "Christmas Eve is looked upon almost as a day of fasting and they eat no meat; everything else they collect together and consume on that day at one small meal. This they do especially on Christmas Day [...] which morsels set and aside and gathered together they put in a container of birch bark which is formed in the shape of a boat equipped with mast and sail and oars and on top of this they pour a little fat. This container they then place about a musket shot from their tents in a tree; this they wish to give to the errant Christmas folk who they believe wander abroad in the air" (Rheen 1897, 27).

By "Christmas folk" are meant the dead referred to by Grundström "There is a particular time of the year when the dead wander abroad. That is Christmas. It is then that crying and wailing can be heard. It sounds as though people were out and about, travelling. Nothing can be seen. The dogs become restless [...] What is it that has caused this unrest? Yes, the dead who arise at Christmas to visit their old homes. But they are no longer called the dead but "Christmas goats" (Grundström 1950, 54). The Saami version of the wanderings of the dead is connected in part with the western Norwegian oskorei idea, in part with conceptions of sirens but also with Celtic materials that have been elicited by Reidar Christiansen in his work Gaelic and Norse Folklore (Christiansen 1938).

Of considerable interest to anyone studying such folk beliefs is the similarity of conceptions in Finnish-speaking areas. In Das Verhalten der Finnen in heiligen (pyhä) Situationen (Vilkuna 1956) Asko Vilkuna demonstrated how loaded with magic the words pyhä (holy) and väki (folk) are. In Finnish-speaking areas there are beliefs in hiidenväki, a band of dead people travelling through the air with horses and jingling bells. It was dangerous to meet them. Hiidenväki had a strange appearance; in Satakunta they had long noses while in Seiskare they had seven heads, in 
Ingermanland black headscarves. They were abroad the twelve days of Christmas i.e. from Christmas morning to Epiphany-the same period that the Christmas goats of Scandinavian traditions roam the area among the Lulea Saamis. I do not intend to go into all the problems surrounding the Christmas period of peace encompassed by the twelve days of Christmas. I would simply like to point out that the period of Christmas peace, established by the Hälsinge law, was a firmly established custom in the Nordic countries going back to the official Christmas celebrations laid down by the Catholic church at Tours in 867 (UU Fjellström).

So, in this account told by Rheen, we find

- that Christmas Eve was respected as a day of fasting and "no meat was eaten',

- that beliefs about Christmas folk were common in western Scandinavia and Celtic areas,

- that the Catholic celebrations of the twelve days of Christmas-the period of Christmas peace-was linked with these beliefs and

- that the sacrificial rite took place relatively close to the tent with a sacrificial dish shaped like a boat complete with sail and oars being hung up in a tree, probably a tall tree so that the Christmas folk could reach it on their wanderings through the air.

This last that-clause does not seem to have any Catholic connections but rather pre-Christian ones. In brief, Rheen's quotation appears to contain several different components of tradition, and also several different time strata.

An analysis of these different phenomena can perhaps provide us with what I termed in my introduction as a different phenomenon in Saami materials.

In order to gain access to what lies behind these concrete things-the boat, the Christmas people, the twelve days of Christmas-I shall use both cultural-ecological and tradition-ecological approaches. The ecological and cultural-ecological aspect was of great importance for ethnologists and archaeologists in northern Sweden throughout the 1970's (see in particular Luleälvsymposiet 1981). Steward, who pioneered cultural-ecological methodology in his book Theory of Culture Change in 1955, inspired Hultkrantz, who in turn published what has now become a classic Type of religion in the Arctic hunting cultures (1965). This work was to play a decisive role in my own research. When I wrote my book The Swedish-American colonization of the San Joaquin valley in California in 1970, I took up in particular the cultural-ecological aspect. I also addressed this same aspect in my article Immigrantmiljön och den kultur-ekologiska aspekten (1971), which formed 
part of Ekologi och kultur (ed. Daun-Löfgren, 1971). The Finnish ethnologist Sarmela also described his cultural-ecological research results in the same work. In my article I pointed out the importance of how factors other than simply the physical environment can create cultural patterns and variables. The Luleå Lapp region is taken as an example; here two ethnic communities live side by side with exactly the same resources: mountains, forest, water, reindeer. Yet they nevertheless have very different cultural patterns, different values, i.e. a completely separate cognitive style.

In the article dated 1971 I quote C. Darryl Forde (Habitat, economy and society 1963, 463). He says that "Between the physical environment and man's activity there always exists an intervening layer, a collection of specific goals and values, a store of knowledge and beliefs, in other words, a cultural pattern" (Fjellström 1971, 132).

I continue, "This intervening layer between the physical environment and human activity, which we call culture, traditional pattern, can exhibit an entirely different character within different groups even though they live in identically the same environment [...]"' I also add that the environment, the physical environment, that is, "has, it is true, played a large part in the creative process that has resulted in these patterns but geographical factors must not, as stated in the introductory chapter of the Daun \& Löfgren work, be regarded as determining this process. Quite different factors must also be taken into account-namely the acquired cultural pattern which is handed on, with certain variations (integrated innovations), from generation to generation, the habits, practices, values that are inherited, in other words, the intervening stratum between the physical environment and human activity. This stratum has within it, so to speak, an innate creative mechanism. Here in my opinion lies the focus of expressions of culture" (Fjellström 1971, 132). The end of my quote and so much for my article of 1971.

What now is interesting is that 10 years later Lauri Honko and Orvar Löfgren have published the work Tradition och miljö. Ett kulturekologiskt perspektiv (1981). In it Orvar Löfgren develops a clearly expressed culturalecological approach with which he did not agree in 1971 and Lauri Honko introduces his informative chapter on tradition ecology. It is encouraging to note that Honko's reasoning is closely linked with Darryl Forde and exactly the same quotation that I used in 1971. What Honko describes as the "perceived environment" (Honko 1981, 20), seems to correspond to my thinking on "the intervening layer". Honko has, as I shall demonstrate in the following, realised the importance of a wider cultural-ecological view, which he terms tradition ecology. Cultural ecology, which Hultkrantz has made widespread and which many disciplines have adopted in their re- 
search, has become a key approach in, for example, the interdisciplinary Lule river project at Umeå University. For those natural scientists and archaeologists taking part in the project cultural ecology has been fundamental (Fjellström 1983, 1). Against this background it is rather surprising that one of the leading ethnologists in the Nordic countries should write "Since this model [the ecological] has sometimes proved rather mechanical, in American scholarship the term 'cultural ecology' has appeared, which has not led to any greater clarity" (Bringeus 1978, 41-56). The real import of ecology and cultural ecology seems to be diffuse as far as Bringeus is concerned.

If we now return to Rheen and the birchbark boat in order to try and elicit the cognitive map behind this kind of sacrificial rite, which seems to differ from the norm in the Lulea region, where a reindeer or reindeer's horn was the standard sacrifice to propitiate the gods and get better hunting, if we examine the quotation above and its importance in relation to good fortune when hunting reindeer, then we find that it was not reindeer herding which was the object of this sacrifice but something quite different. Let us now apply tradition ecology to our quotation. In his tradition-ecological model Honko has shown that we can operate with three kinds of environment: the total, the effective and the perceived.

The total environment in this context would comprise the entire physical and geographical surroundings, the effective environment would be how they were exploited (by the Saamis) and how they would affect people whether they liked it or not. These two environments would, so to speak, be looked upon by the scholar standing apart and they would constitute his intellectual tools in his analysis.

In the perceived environment it is man himself who is the object studied, the actual creator of culture. Honko writes "It is his way of perceiving, classifying, verbalising, expressing and pronouncing upon his world which is the guiding principle in definitions of the perceived environment" (Honko 1981, 20). Here Honko quotes the statement made by Forde and "the intervening layer" I mentioned earlier and which Honko prefers to term "Man's cultural pattern of perception".

The Forde quotation adds a sharpness to tradition ecology, which is why I have described this background to the approach in detail.

Let us now go on to analyse in depth the relevant Saami historical, archaeological and philological materials-necessary interdisciplinary aspects in ethnological Saami studies. Then we will cast light once more on our introductory quotation with the aid of cultural and tradition ecology. When we first come into contact with a Saami area which we know has been inhabited by Saamis, it is with their language. There are no written 
Saami sources that could provide us with a firm prehistorical basis to stand on. Therefore an interdisciplinary approach is absolutely indispensable in Saami studies. Philology is one such fundamental tool, archaeology another.

What helps us to penetrate a Saami community in the centuries just after the birth of Christ are Norse loanwords in Saami. We know from philology that certain rules obtained for the pronunciation of Old Norse in the period A.D. 200-600. In the Saami language there are certain words borrowed from Norse which are characterised by these special laws of pronunciation. The words cannot have been borrowed as late as A.D. 800, for example. The area in which this process took place must have laid somewhere in northern Norway, in the Tromsö-Saltdalen region. This is how K. B. Wiklund (1911, 1947), Collinder (1965), Sköld (1961) and Qvigstad (1893) reason. What kinds of words did the Saami inhabitants borrow? The answer is Norse loanwords connected with different kinds of work: boatbuilding, milk production, new settlement, etc. According to Collinder the Saamis, who lived deep in the fjords-the Norwegians lived at the mouths of the fjords -learned to build boats, to milk, etc. at the same time that they learned the words to describe these activities. I am of another view and have discussed these problems in my book Samernas samhälle i tradition och nutid (1985).

When the Norwegians moved in a continuous flow, from the period before the birth of Christ, and even earlier, for several centuries onward up from southern Norway to settle the virgin lands of the north along the coastal strip (Sjøvold 1974; Johansen-S $\varnothing$ bstad 1978), they needed labour to help them. As with all forms of new settlement, the colonists lived far apart. They needed helping hands to clear the land, to build boats, to transport timber, to milk cows and to tend them.

These helping hands were to be found in the deepest parts of the fjords. It was there that the sea Lapps lived on fishing and bird-catching, not by herding reindeer. They had fixed dwellings and were not nomads. They probably had a goat or two and they exploited the forest for their own needs (Vorren \& Manker 1976). Fishing was their mainstay. Surely these Saamis would have been able to build boats, living as they had for hundreds by the water. They must have known the skills of boat-building. If we now assume that the Saamis and the Norsemen worked side by side at the jobs involved in new settlement, they must have been able to communicate with each other. The Saamis therefore adopted the Norse term, "lappicised" it and forgot the original Saami word. In this way the uppermost plank of a boat came to be known as rapmo, a word of Norse origin. These Norse loanwords do not constitute a large vocabulary in the Saami language but they are terms typically used by settlers and workers (Nesheim 1953, Collinder 1965). 
The Saamis living along the northern coast of Norway lived on fishing and other things taken from the sea. They made ship's cables of whale and seal skins, as Ottar tells us as early as A.D. 800. At that time they had already begun to keep reindeer to some extent-wild reindeer were tamed -but Ottar says nothing about nomadism. It was still the sea that provided them, in the main, with their livelihood; they gathered eider feathers and hunted seals and whales. Not a word is mentioned by Ottar about milking reindeer or about reindeer cheese. Such things indicate intensive reindeer, i.e. the care and grazing of herds of reindeer. This formed the kernel of the nomadism which was to emerge during late Mediaeval times when migrations, raids, the movable Saami tent became the main feature of the mountain Saamis' life, and by this are meant Swedish and Norwegian mountain Saamis south of the Troms area.

The mountain Saamis of the Norwegian part of Finnmark along the Arctic coast did not enter the picture until quite late-not until the 17 th century. In Finland there lived forest Saamis with quite a different life during the Middle Ages-the hunting of wild reindeer and fishing were combined there.

Even a thousand years after the birth of Christ the north-Norwegian sea Saamis were still living in fixed dwellings, in their cabins, they were still fishing, did not go on nomadic wanderings even though they had started to tame wild reindeer. One might well ask if they did not tame the wild reindeer to use them as transport animals. The reindeer was absolutely indispensable for transport in the mountains; horses, on the other hand, had difficulties in the deep snow. When the process of domestication had once begun it was only natural to tame the reindeer properly and make use of them in the same way that the Norsemen did with their cattle.

From this it should be clear that a large group of Saamis-the sea Saamis in northern Norway-have lived and still live by the sea. They probably constitute the largest group of Saamis in western Scandinavia. Some of these Saamis were no doubt able to hunt elk (there are elk bone finds dating back to 4000 B.c. at Hoting in northern Ångermanland, Sweden) and later wild reindeer. The custom of using pit traps on the Swedish side is an indication of such hunting activity. With time there gradually developed mountain nomadism on a small scale in the Swedish areas inhabited by the Saamis-wild reindeer were tamed, guarded, cared for, milked. It therefore seems not unlikely that the hunting coastal Saamis in Norway also took to this new kind of livelihood, too-we know from Ottar that they had such herds of tame reindeer-and that they perhaps settled beside Swedish mountain lakes (Fjellström 1985). 
Let us now return to Rheen and his birchbark boat while at the same time still keeping the coastal Saamis in mind.

Honko writes, "Legends, recollections, prayers, magic spells, beliefs and rites form groups in the natural environment as tradition territories. These are based to a large extent on economic niches but it should be remembered that man's conquest of his surroundings is not just and expression of economic activity: the cognitive conquest is equally important, i.e. attempts to organise, divide, classify, name and so dominate one's environment"' (Honko 1981, 33).

This statement of Honko's I take to be decisive in an analysis of Saami pre-Christian religion, which seems to exhibit several layers of belief. This, it would seem, is the result of their attempts to organise their surroundings in order to cognitively master a new physical environment.

For a fishing people (the north-Norwegian sea Saamis) living near the water-their economic niche-the cognitive domination of what formed their environment was important. They already controlled their effective environment-fishing, nets, boats, etc.-but in order to achieve cognitive dominance theses sea Saamis, these creators of culture, had to perceive their environment in such a way as to be able to classify it, give it a name, master it-all in order to master their life situation. For them it must have been a necessity to have power over the forces of the weather by means of concrete concession measures, i.e. ritual behaviour with sacrifices or the like; similarly to give them a name, to classify them. They had to have "cognitive maps" that reflected their world view.

Let us now see if such material is to be found in old sources. We can all immediately agree that the sources that we have-17th and 18th century archive records-are much too late. What can 16th-century materials tell us about Saami religion in A.D. 500? Clearly, this is the real difficulty, the absence of sources. However, it happens that the components of human traditions from the past have an amazing vitality. They lie hidden deep within the cultural heritage; sometimes they peep up through the layers of later deposits, sometimes they are discovered anew, they are still visible but we just have not noticed them since we have not had the right tools, we have not had our eyes about us.

As an ethnologist I think that we are constantly surprised by this special internal current of ideas which surrounds our beliefs and which lives on beneath the surface, so to speak, of human life with such a vitality.

What do the sources tell us about the coastal Saamis' "perceived environment'? I have used Nensén's materials as part of my sources. Nensén is very careful as both recorded and abstractor. Nensén noted down from Carl Renmarck, who on September 1, 1742 in Luleå wrote a "list of some of 
the gods of converted Lapps". I have also used materials from Thomas von Westen's circle. Among these, Samilin, for example, speaks of Giase olmai- "the water god" - one who rules and reigns over the water (Reuterskiöld, 14).

Solander, another member of this circle, says that sacrifices were offered to Biex-Ollma "[...] a god of the weather who lives up in the sky; to him are promised offerings when the weather is very strong [...]. The health of this Biex-Ollma must be drunk at Christmas ..." (Reuterskiöld 1910, 23). Hans Skanke also mentions this same "Bjegs-Galles, the god of the wind, who casts out weather and storm with his shovel, which is called Koiwo" (Reuterskiöld 1910,100). Harva points out that the Saamis got their beliefs about a particular water spirit, tjatse-halde, from the Finns. According to Fellman Finnish Saamis offered silver coins to this spirit so that it should grant them good harvest from the waters: fish, beaver, pearls.

Nensén has described "Namma-quele, the name fish, whose help is granted to few since not everyone has known about him. They obtain his help when someone is baptised by Magic Baptism more than once; according to this, when someone falls sick he is given another name and water is poured over him with the following words: I baptise you with this name $\mathrm{N}$. $\mathrm{N}$. and you shall live with this name N. N. Those who are christened in this way may also take the name Nammaqwele, and the Lapps often see Nammaqwele going over streams and bogs. Then they see him also when they go to church and when they go to confession, they drink of the blood of Sarakka in the same stream where Nammaqwele lives" (UUB Nensén, 656). In the Nensén quotation Christianity and pre-Christian rites are interwoven in a tangible way; in other words, we see here different cognitions that come into conflict. Randulf says that the north-Norwegian Saamis turned to the sea god Tonsie to obtain good fortune at sea and to Harchild for success when fishing in rivers and lakes (UUB Harva, 827). Nensén (after Renmarck) writes of Piäggesvålma = governs weather and wind, sea and water and has received offerings in order that he might allay storms at sea" (UUB Nensén, 654).

This must refer to the same god mentioned by Skanke and Solander. What is interesting is that Randulf reports that certain small artefacts "namely small boats" were offered to this "wind man" and Forbus says that "to him is offered a shovel made of wood (Reuterskiöld 1910, 33). Harva was of the view that this shovel was the rudder (steering oar) of a boat (UUB Harva 142, 829).

Our analysis is now approaching the birchbark boat referred to by Rheen, the boat equipped with sail and oars, soaked in fat and placed up in a tree. However, this birchbark boat was not sacrificed to some spirit of the wind 
but to the Christmas people who "travel abroad in the air" at Christmas. Such an offering was made by mountain Saamis with large herds of reindeer in the Luleå area in the 16th century. - Rheen recounts throughout Tuorpon and Sirkas Saami conditions. - Among these very traditionbound Saamis we find a ritual custom that would seem to have belonged to quite a different economic niche-probably that of the sea Saamis-but was transferred to a new niche, that of the mountain Lapps with quite a different structure. How is this possible? Honko writes about environment-morphological adaptation: "In the first place narratives and traditions of foreign origin often contain descriptions of natural environments that are less wellknown. These elements must sometimes be replaced by familiar features from the community's own physical surroundings, i.e. it is the process of familiarisation" (Honko 1981, 31).

Here the description of the closeness to the "Saami tent environment" and the forest landscape that surrounds the Luleå Saamis in the winter is a form of familiarisation. It is not a seascape or winds blowing over water that is described in this case. The ritual behaviour described in Rheen's quotation-about offering up a birchbark boat and abstaining from meat at Christmas-represents a different world, in brief a different world picture than that recommended by the 17th-century Lutheran environment. But the sacrificial rite seems to have undergone several stages of adaptation and has become consistent with the reindeer-herding environment of the Luleå Lapps.

This is what Honko terms tradition-morphological adaptation and it is particularly obvious when "[...] foreign traditions [...] enter an environment". By environment is meant the tradition environment bearing the marks of the individual's experiential and perceived world and determined by socioeconomic structures, role, value and norm systems (Honko 1981, 35). What can possibly be extracted from Rheen's quotation against the background of the historical account I have given above is that the boat that was probably offered to the wind god by the coastal Saamis in prehistoric time as an expression of ritual behaviour lives on centuries later in an adapted form among mountain Saamis. During the Middle Ages Catholic features were added, under the influence of the Catholic church and Catholic beliefs (there was a Catholic church in the Troms region, "ecclesia sancta Marie juxta paganos") (Fjellström 1962, 259).

The Catholic faith seems to have had a strong influence on Saami society and Saami beliefs (cf. Rheen's reference to fasting, the Christmas people). Lutheran contributions are remarkably few in Saami folklore material. When the socioeconomic structure changed, i.e. when reindeer herding became the Saamis' principal source of economic welfare, then offerings of 
reindeer horns, whole reindeer and reindeer blood new sacrifical symbols by means of which to obtain good fortune. Nevertheless, the cognitive trappings of times long past still seem to have lived on in the form of offerings to the water spirit, the god of fishing or to the wind spirit, a birchbark boat as described by Randulf.

Among the Lulea Saamis, however, the birchbark boat was offered to the Christmas people, not to the water spirit or wind god. Why? Honko says, "New elements of tradition are adapted in accordance with the best-known tradition, i.e. collective tradition, so that their message will take effect" (Honko 1981, 35).

Therefore we find the Christmas people-the dead as the group to whom the birchbark boat offering was made. It was the message that best reached the collective, i.e. the Saami sita.

The water man, the fishing god who reigned over sea and storms, was not relevant among the Lulea Saamis in the 17th century. The Christmas people, on the other hand, were. Catholic customs lived on. The birchbark boat, which seems to be quite irrational as a symbol, seems nonetheless to have had a rational significance. This, in my view, is what an analysis from a tradition-ecological perspective can help us to realise.

By applying culture-ecological and tradition-ecological ideas to certain ritual behaviour among the western Saamis in the past I have tried to extrapolate the perceived environment that I have found remarkably split in their cognition. The concept of perception is topical in this context since it implies that information received by the senses is interpreted in a certain way. Through the process of learning an extremely large mass of information is stored in the brain. We then use this information in order to interpret what we have perceived and give it a meaning. But-and this is something which our 17th-century quotation concerning the birchbark boat seems to indicate-people experience and interpret information in different ways according to what might be termed cognitive style. Moreover, it is quite clear that a persons' cognitive experience is expanding all the time and that each new piece of information changes the person's cognitive map.

The creative process that has led to this adaptive behaviour, the dynamic "intervening layer" between the natural environment and human activity is the basis of all culture, what we take with us as cognitive style. "Between the physical environment and human activity, there is always a middle term, a collection of specific objectives and values, a body of knowledge and belief, in other words, a cultural pattern" (Forde 1968, 463).

As early as 1970 I championed this culture-ecological method and, it still seems to be a useful tool for analysing different cultural phenomena. The 
tradition-ecological evolved by Honko provides us with an even finer tool with which to analyse beliefs and ritual behaviour.

\section{Bibliography}

UNPUBLISHED SOURCES

Umeå

UU Umeå universitet, Etnologiska institutionen

Fjellström, Ph. Julfrid, vårfrid och andfrid - rättsseden i folkligt kalendarium. Stencil.

Uppsala

UUB Uppsala universitetsbibliotek

[Harva], U. Lapparnas religion. [By] U. Holmberg-Harva. [Transl. by] P. A. Boreman. K. B. Wiklunds samling nr 147. 75, 8.

Nensén, J. A. Samlingar ang. svensk och norsk folklore, ekonomi [...] 2. R 650.

PUBLISHED SOURCES AND LITERATURE

Bringéus N.-A. 1978. Folklig kultur och social struktur. Rig.

Christiansen, Th. R. 1938. Gaelic and Norse folklore. Folkliv.

Collinder, B. 1948. K. B. Wiklund ( $\dagger$ ), Lapparna. Svenska Landsmål. Review. Uppsala.

- 1965. Lapparna. Kulturhistoriskt lexikon för nordisk medeltid 10. Helsingfors.

Daun, Å. \& Löfgren, O. 1971. Den ekologiska aspekten. Nord-nytt 2.

Ekologi och kultur. 1971. [Ed. by] Å. Daun \& O. Löfgren. København.

Fellman, J. 1906. Anteckningar under min vistelse $i$ Lappmarken 1-4. Helsingfors.

Fjellström, Ph. 1962. Lapskt silver 1-2. (Skrifter utg. genom Landsmåls- och folkminnesarkivet i Uppsala C, 3.) Uppsala.

- 1970. Swedish-American colonization in the San Joaquin Valley in California. (Studia ethnographia Upsaliensia 33.) Uppsala.

- 1971. Immigrantmiljön och den kulturekologiska aspekten. Nordnytt 2.

- 1983. Luleälvsprojektet. Ume-etnologi 2.

- 1985. Samernas samhälle $i$ tradition och nutid. Stockholm.

Forde, C. D. 1963. Habitat, economy and society. London.

Grundström, H. 1942. Tro och övertro bland lapparna. Svenska Landsmål 65. Uppsala.

- 1950. Folklig tideräkning i Lule lappmark. Svenska Landsmål 73. Uppsala.

Honko, L. 1981. Traditionsekologi - en introduktion. Tradition och miljö. [Ed. by] L. Honko \& S. O. Löfgren. Lund.

Hultkrantz, A. 1965. Type of religion in the Arctic hunting cultures. Hunting and fishing. [Ed. by] H. Hvarfner. Luleå.

Itkonen, T. I. 1946. Heidnische Religion und späterer Aberglaube bei den finnischen Lappen. (Mémoires de la Société Finno-Ougrienne 87.) Helsinki.

Johansen, O. S. \& Søbstad, T. 1978. De nordnorske tunanleggene fra jernalderen. Viking 41 . 
Luleälvssymposiet. 1981. (Skrifter från Luleälvsprojektet 1.) [Ed. by] Baudou \& Nejati. Umeå.

Nesheim, A. 1953. Noen nordiske ord- og kulturlån hos samene. (Studia septentrionalia 5.) Oslo.

Qvigstad, J. K. 1893. Nordische Lehnwörter im Lappischen. (Christiania Videnskabs-Selskabs Forhandlinger 1893, 1.) Christiania.

Randulf, J. 1903 (1723). Relation anlangende Find-Lappernis [...] af Guderier og Sathans dyrkelser [. . .] Kildeskrifter til den Lappiske Mythologi 1. [Ed. by] J. Qvigstad. (Det Kgl. Norske Videnskabers Selskabs Skrifter 1903, 1.) Trondhjem.

Reuterskiöld, E. 1910. Källskrifter till lapparnas mytologi. (Bidrag till vår odlings häfder 10.) Stockholm.

Rheen, S. 1897. En kortt Relation om Lapparnes Lefwarne och Sedher [...] Svenska Landsmål 17, 1. Uppsala.

Sarmela, M. 1971. Kulturekologiska forskningsaspekter. Nordnytt 2.

Sjøvold, T. 1974. The iron-age settlement of Arctic Norway. (Troms $\varnothing$ museums skrifter 10, 2.) Oslo.

Sköld, T. 1961. Die Kriterien der urnordischen Lehnwörter im Lappischen 1. (Skrifter utg. av Institutionen för nordiska språk vid Uppsala universitet 8.) Uppsala.

Steward, J. H. 1955. Theory of culture change.

Wiklund, K. B. 1911. Zur Kenntnis der ältesten germanischen Lehnwörter im Finnischen und Lappischen. (Le monde oriental 5.) Uppsala.

- 1947. Lapparna. Nordisk kultur 10. Stockholm.

Vilkuna, A. 1956. Das Verhalten der Finnen in ,Heiligen" (Pyhä) Situationen. (FF Communications 164.) Helsinki.

Vorren, Ø. \& Manker, E. 1976. Samekulturen. Oslo. 